In Search of Lost Meaning 
The publisher gratefully acknowledges the generous support of the Humanities Endowment Fund of the University of California Press Foundation. 


\title{
In Search of Lost Meaning
}

\author{
The New Eastern Europe
}

\author{
Adam Michnik
}

Edited by Irena Grudzińska Gross

Translated by Roman S. Czarny, with a Foreword by

Václav Havel and an Introduction by John Darnton

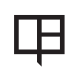

UNIVERSITY OF CALIFORNIA PRESS

Berkeley Los Angeles London 
University of California Press, one of the most distinguished university presses in the United States, enriches lives around the world by advancing scholarship in the humanities, social sciences, and natural sciences. Its activities are supported by the UC Press Foundation and by philanthropic contributions from individuals and institutions. For more information, visit www.ucpress.edu.

\section{University of California Press}

Berkeley and Los Angeles, California

University of California Press, Ltd.

London, England

(C) 20II by The Regents of the University of California

Library of Congress Cataloging-in-Publication Data

Michnik, Adam.

[W poszukiwaniu utraconego sensu. English]

In search of lost meaning : the new Eastern Europe / Adam Michnik; edited by Irena Grudzinska Gross ; translated by Roman S. Czarny, with a foreword by Vaclav Havel and an introduction by John Darnton.

p. $\mathrm{cm}$.

Includes index.

ISBN 978-0-520-26923-I (alk. paper)

I. Social ethics. 2. Social ethics-Poland. 3. Poland-Politics and government1980-1989. 4. Social change-Europe, Eastern. 5. Social change-Poland. 6. Europe, Eastern-Politics and government-1945-1989. 7. Europe, Eastern-Politics and government-1989- 8. Europe, Central-Politics and government—1989- I. Grudzinska Gross, Irena II. Title.

$$
\begin{aligned}
& \text { нм665.M53413 } 2007 \\
& 303.48^{\prime} 4094380904-\mathrm{dc2} 2
\end{aligned}
$$

2010040640

Manufactured in the United States of America

$$
\begin{array}{lllllllllll}
\text { 20 } & \text { I9 } & \text { I8 } & \text { I7 } & \text { I6 } & \text { I5 } & \text { I4 } & \text { I3 } & \text { I2 } & \text { II } \\
\text { I0 } & 9 & 8 & 7 & 6 & 5 & 4 & 3 & 2 & \text { I } &
\end{array}
$$

This book is printed on Cascades Enviro Io०, a 1o०\% post consumer waste, recycled, de-inked fiber. FSC recycled certified and processed chlorine free. It is acid free, Ecologo certified, and manufactured by BioGas energy. 